(8)

ISSN 1997-3187

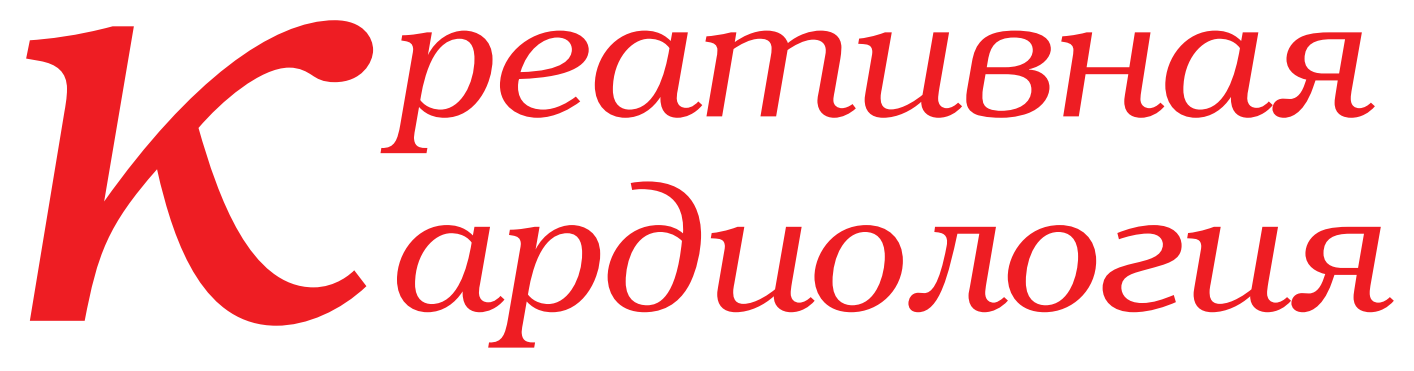

\title{
Creative Cardiology
}

$$
\begin{gathered}
\text { T. } 12 \text {, № } 4 \\
2018
\end{gathered}
$$

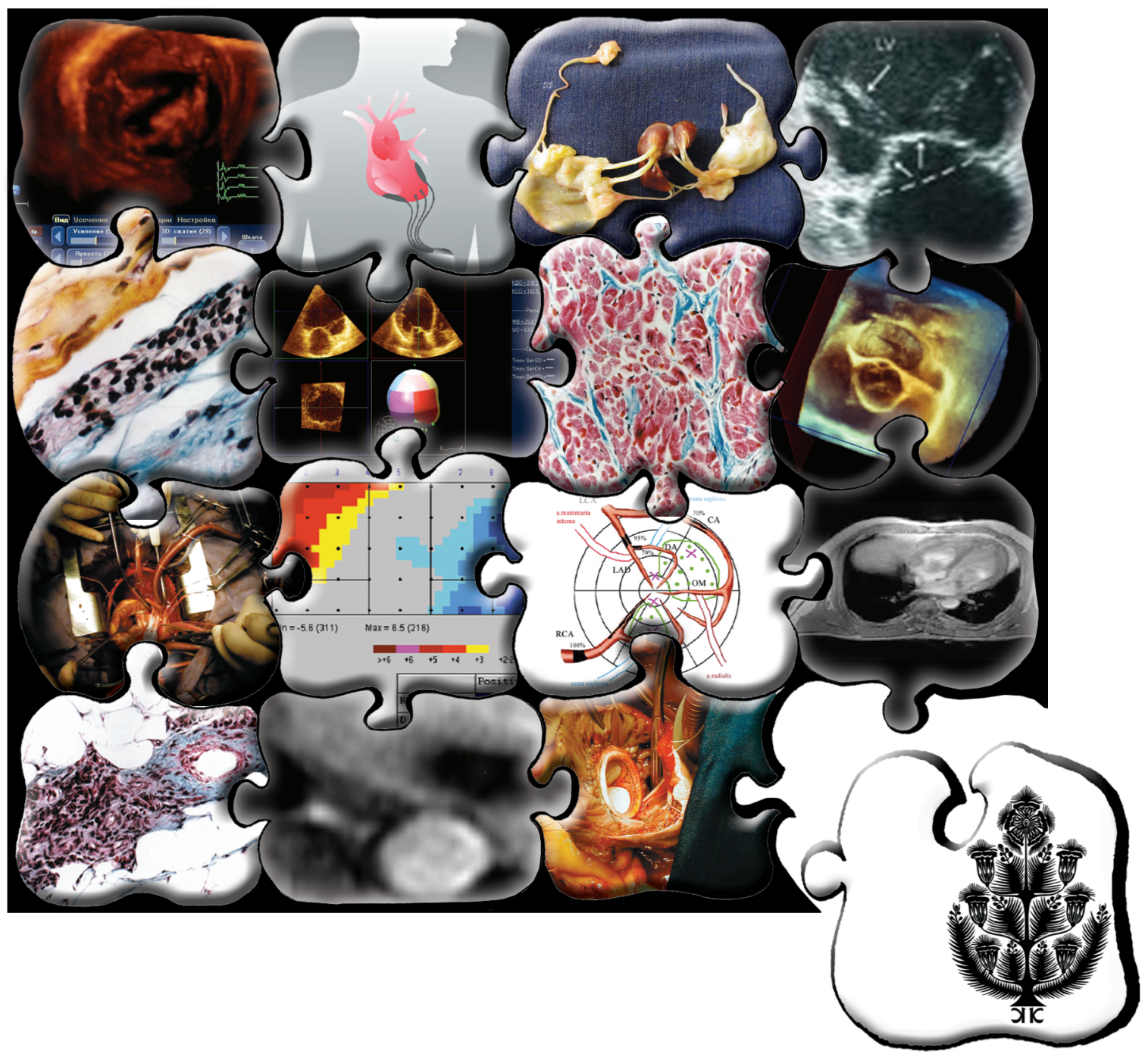

